\title{
Review of Dramaturgy in the Making: A User's Guide for Theatre Practitioners.
}

Dramaturgy in the Making: A User's Guide for Theatre Practitioners. By Katalin TRENCSÉNYI. London: Bloomsbury Methuen Drama, 2015. 352pp. ISBN 978-1-4081-5567-7.

Trencsényis first solo publication on the subject of the theory and practice of dramaturgy follows New Dramaturgy: International Perspectives on Theory and Practice, co-edited with Bernadette Cochrane (2014). Advertised as 'a user's guide', the book does what it says on the cover. Capturing dramaturgy in the state of its continual development and flux, the foreword by Geoff Proehl sets the scene, evading the ever-lingering question 'what is dramaturgy?'. Instead, Trencsényi offers a wellresearched account of examples of dramaturgical practices across Europe and North America, and diachronically maps the development of the practice of dramaturgy from Lessing to contemporary dramaturgy practitioners in text-based theatre; in discovering the historical roots of dramaturgy she even goes as far back as Lucian. Whilst the historical overview is useful, Trencsényi is perhaps too keen on sketching out the history of dramaturgy rather than concentrating on contemporary practice and its implications, however she does attempt to outline the legacy of thinkers and practitioners such as Lessing, or Tynan.

Chapter 1 is concerned with 'institutional dramaturgy', claiming that the role of the dramaturg emerged together with bourgeois drama and the emergence of na- tional theatres. Here, the author details the practice of Lessing in Germany and the emergence of the literary manager in the UK and USA. Whilst the overview is useful, this has been described before and the legacy of Lessing and Tynan in contemporary dramaturgy is perhaps not as strong as the author suggests because these examples concern the chosen few who worked in established theatre institutions in very specific contexts.

Chapter 2 outlines the methods of curating, linking the practice to literary management and the implications of choosing a theatre repertoire and planning a theatre season. Particularly useful are the examples of curatorial practices employed by the practitioners preparing various festivals as this is something a 'user' of this book might get involved in.

Chapter 3, perhaps slightly out of character with the rest of the publication, talks about dramaturgy and translation. Trencsényi chooses to provide examples from two established UK theatres: The Royal National Theatre and The Royal Court with their differing but also very specific practices of working with plays in translation. These two examples are perhaps not representative of the wider current practice of working with foreign text and, whilst it outlines the practice of NT (working with 
'literal' translations) and the RCT (working with 'translation proper'), little space is given to the practice of collaborative translation, which differs from the practice of the Royal Court.

Chapter 4 places the dramaturg at the heart of theatre-making and new play development. The author takes us back to the Royal Court in 1956 and provides interesting examples of new play development in North America - with particular attention to the dramaturgical process. The examples of practice here give an interesting insight into specific play development processes with a particular emphasis on the dramaturg's personality and behaviour in the process. Whilst the 'ways of collaborating' are very important in the process, they are not necessarily restricted to the work of the dramaturg, which is at the centre of Trencsényi's attention, but apply to the entire collaborative team.

Chapter 5 talks about 'production dramaturgy', emerging from the practice of Bertolt Brecht and taking the reader towards contemporary practice. Whilst the director is clearly defined, the production dramaturg gets the 'in-house critic' tag and Trencsényi in these historical examples cannot escape describing a hierarchical structure in which the dramaturg is often guarding the 'vision' of the director. The author makes an interesting link in the emergence of the role of production dramaturg out of conflict and the emergence of new forms and fundamental questions about the role of the theatre. Trencsényi claims that this may have led to the misunderstanding of the dramaturg as an ideological manipulator, but she provides no evidence of this kind of misunderstanding. Perhaps the most important dramaturgical approach highlighted in the historical examples is in treating the playtext as raw material and in re-examining the classics. Trencsényi then moves on to the origins and development of non-text-based theatre which she calls 'new dramaturgy', removing the dramaturg's tag as the 'third eye' and an 'in-house critic', and moving towards the more collaborative ways of working that chime with current practices.

Chapter 6 describes the four stages of 'product-led' dramaturgy, mapping the development of two continental productions (produced in the Netherlands and Hungary) across four stages. What is useful here is to see the different approaches to production dramaturgy employed by two very different companies. Trencsényi highlights particularly the director-dramaturg collaboration, inadvertently placing the dramaturg in a submissive position again, one responsible for co-creating the 'director's copy' of the playtext, being given a 'free hand' from the director to work on certain aspects of the production. Both the examples given deal with production processes for playtexts at which the playwright was absent (canonical texts), in which actors were invited to collaborate only once the director-dramaturg team had decided it was time. The author again pays particular attention to the 'demeanour' of the dramaturg and the implications of one's personality on the creative process, which is perhaps important but difficult to evaluate.

Chapter 7 makes a distinction between product- and process-led dramaturgy, in which the author describes the shift from text-based theatre to devising practices and the implications of this for the dramaturg. Whilst there are parallels with the four 
stages of development present in text-based theatre, Trencsényi acknowledges that the traditional hierarchies are often absent from the process-led dramaturgy. On the case study of a Shunt production, she makes an important link between the linear dramaturgy' of the piece and the tunnel-shaped performance space. She does not forget to mention the role of the audience as an important collaborator.

Chapter 8 deals with the emergence of dance dramaturgy as a separate discipline in the nineteenth and twentieth centuries, she looks back to Lucian and makes a daring leap all the way to the present. Here the author asks fundamental questions about the purpose of the dance dramaturg which she answers in the next chapter.

Chapter 9 is largely concerned with contemporary dance dramaturgy and the emergence of first dance dramaturgs in Europe and the US in the 1980s. Trencsényi masterfully navigates the unexplored waters of dance dramaturgy, giving interesting examples of concrete practice between dance dramaturgs and dancers or choreographers (Ruth Little, Akram Khan and others).

Chapter 10 details the different stages of development in dance dramaturgy on the examples of Out of Context by les ballets $C$ de la $B$ and DESH by Akram Khan. Again, the author offers an interesting contrasting insight into two productions created in different ways, yet following the established dramaturgical pathways. Particularly illuminating is Ruth Little's open attitude to the instability of the process and its implications for the final production.

Trencsényi concludes by offering 'the two things' that are most important about dramaturgy, which in her opinion are to
'Support' and to 'Challenge'. Whilst I agree that the author provided many examples of the ways in which dramaturgs support their directors and actors and challenge the creative processes, perhaps the two things being framed as to 'Collaborate' and to 'Create' would bring them into a more equal relationship with the other members of the creative team.

Whilst providing plenty of useful examples of dramaturgical practice, Trencsényi tends to remain descriptive where a deeper analysis would be useful. Her 'user's guide' only makes links to theoretical practices in her historical overview, which often repeats what has already been written on the subject of Lessing, Brecht or Tynan. Her book claims to be a guide for theatre practitioners, yet this publication appears to be more appropriate for students of dramaturgy, emerging dramaturgs, as well as more established dramaturgs. Also, whilst providing examples of dramaturgical practice in the UK, Trencsényi does not offer an assessment of the on-going issue of professionalising the role of the dramaturg in Britain, nor does she provide a comparison with dramaturgs working in continental Europe. The publication's strength is in providing a wealth of examples from the UK, North America and continental Europe that demonstrate dramaturgical practice in media res: i.e. by showing different ways of working using illustrations drawn from concrete projects, or by selecting contrasting productions that follow the same dramaturgical model and yet work very differently in practice.

DOI: 10.5817/TY2015-2-20 